\title{
Urgences
}

\section{SUNT GEMINAE...}

\section{Andrea Moorhead}

Numéro 15, octobre 1986

Épigraphiques

URI : https://id.erudit.org/iderudit/025354ar

DOI : https://doi.org/10.7202/025354ar

Aller au sommaire du numéro

Éditeur(s)

Urgences

ISSN

0226-9554 (imprimé)

1927-3924 (numérique)

Découvrir la revue

Citer ce document

Moorhead, A. (1986). SUNT GEMINAE... Urgences, (15), 97-97.

https://doi.org/10.7202/025354ar

Ce document est protégé par la loi sur le droit d'auteur. L'utilisation des services d'Érudit (y compris la reproduction) est assujettie à sa politique d'utilisation que vous pouvez consulter en ligne.

https://apropos.erudit.org/fr/usagers/politique-dutilisation/
Cet article est diffusé et préservé par Érudit.

Érudit est un consortium interuniversitaire sans but lucratif composé de l'Université de Montréal, l'Université Laval et l'Université du Québec à Montréal. Il a pour mission la promotion et la valorisation de la recherche. https://www.erudit.org/fr/ 


\section{Andrea Moorhead}

Sunt geminae somni portae

Virgile: L'Enéide, chant VI

\section{SUNT GEMINAE SOMNI PORTAE,}

enfant de douleur, de notre deuil,

jeune homme, la nuit grande et nuageuse,

laisse-moi semer des lys et ces fleurs rouges-sauvages,

ces cadeaux délicats, fragiles,

terre à l'envers du rêve,

terre à l'envers du sommeil,

jumeaux, unis, dont l'ombre nous dépasse,

ombre de ces fleurs rouges, ombre des lys

parsemés à travers le Saint-Laurent,

ombre trop puissante,

grande et invisible

une histoire lue en double sens:

porte aux morts et à l'avenir

porte aux vivants et au passé figé dans nos rêves,

souvenir plus amer,

enfant de douleur, de notre deuil,

jeune homme à côté d'un grand rêve, infusé des laits célestes,

infusé du sang, versé dans ce parterre,

rouge, scintillant,

un corps dans l'ombre, l'autre qui parle encore,

dont le lignage est établi, propagande dont même Orphée

tisse une chanson de douleur,

naissance d'une fleur

cet enfant du soleil. 